\title{
Pelatihan Penerapan PSAK 71 (Instrumen Keuangan) pada Perusahaan Daerah Air Minum di Wilayah Sumatera Selatan dan Bangka Belitung
}

\author{
Tertiarto Wahyudi ${ }^{1 *}$, Anisa Listya ${ }^{1}$, Ubaidillah ${ }^{1}$, Ruth Samantha Hamzah ${ }^{1}$ dan Nur Khamisah ${ }^{1}$ \\ ${ }^{1}$ Fakultas Ekonomi, Universitas Sriwijaya, Sumatera Selatan, Indonesia \\ *Email korespondensi: tertiarto_wahyudi@unsri.ac.id
}

Info Artikel: Diterima: 18 Desember 2020; Disetujui: 29 September 2021; Dipublikasi: 03 November 2021

\begin{abstract}
Abstrak: Kegiatan Pengabdian Kepada Masyarakat ini bertujuan untuk memberikan pendampingan kepada bagian pengelolaan piutang usaha Perusahaan Daerah Air Minum di Wilayah Sumatera Selatan dan Bangka Belitung untuk mengestimasi besarnya penyisihan piutang tidak tertagih dengan menggunakan Expected Loss Method. Metode kegiatan ini dengan memberikan penyuluhan dan pendampingan kepada PDAM dalam membuat perhitungan estimasi piutang tak tertagih. Hasil pengabdian masyarakat ini ditandai dengan antusias dan kemampuan peserta dalam menerima materi dan mampu melakukan praktik untuk menghitung penyisihan piutang usaha dan penurunan nilai piutang usaha. Hasil kegiatan ini diharapkan bermanfaat bagi PDAM untuk meningkatkan pengelolaan piutang usaha yang nantinya akan meningkatkan pendapatan PDAM dan Pendapatan Asli Daerah.
\end{abstract}

Kata Kunci: Piutang Usaha; Expected Credit Loss Method; Instrumen Keuangan; Cadangan Kerugian Penurunan Nilai, PDAM.

\section{Kutipan:}

Wahyudi, T., Listya, A., Ubaidillah, Hamzah, R.S., \& Khamisah, N. (2021). Pelatihan Penerapan PSAK 71 (Instrumen Keuangan) pada Perusahaan Daerah Air Minum di Sumatera Selatan dan Bangka Belitung. Sricommerce: Journal of Sriwijaya Community Services, 2(2): 97-104. DOI: https://doi.org/10.29259/jscs.v2i2.37

\section{PENDAHULUAN}

Perusahaan Daerah Air Minum merupakan perusahaan yang memiliki aktivitas dalam menyediakan air bersih yang mutlak diperlukan oleh dalam kehidupan sehari-hari. Dalam semua aktivitas kehidupan manusia membutuhkan air baik untuk rumah tangga maupun dalam dunia usaha (Yuliani dan Rahdriawan, 2015). Jika ketersediaan air bersih tidak memadai dengan baik, maka dapat menyebabkan munculnya berbagai permasalahan di masyarakat seperti kegiatan rumah tangga dan pelayanan bagi masyarakat terganggu, perusahaan yang membutuhkan supply tidak dapat melaksanakan kegiatan usahanya. Maka dari itu air memiliki peranan penting bagi berbagai sektor kehidupan sehingga air merupakan bagian dari manusia yang tidak dapat dipisahkan dalam kesehariannya.

Perusahaan Daerah Air Minum (PDAM) merupakan perusahaaan milik pemerintah Daerah yang bergerak di sektor jasa, yang ditunjuk sebagai pengelola air bersih bagi masyarakat. Pengelolaan piutang sangat penting bagi perusahaan. Beberapa hal yang diperhatikan dalam pengelolaan piutang adalah mengetahui prosedur penjualan kredit yang dilakukan perusahaan, metode penyisihan dan penghapusan piutang dalam pengelolaan piutang, perputaran piutang dan jumah hari dalam piutang serta kebijakan kredit yang diberikan kepada setiap pelanggan. Piutang adalah akibat dari penjualan kredit yang dilakukan oleh perusahaan. Prosedur penjualan harus 
dibuat agar setiap kegiatan penjualan dapat berjalan dengan baik. Sebelum melakukan penjualan perusahaan harus terlebih dahulu memberikan kebijakan kredit. Untuk meminimalkan risiko gagal bayar setiap pelanggan, bagian akuntansi bertugas untuk menganalisa keadaan keuangan setiap pelanggan.setelah itu, piutang yang muncul harus dikelola dengan baik yaitu dengan membuat tabel umur piutang sehingga manajemen mengetahui kapan piutang itu ditagih (Kesuma et.al., 2020).

PDAM memiliki tujuan jangka pendek untuk meningkatkan Pendapatan Asli Daerah dan bergerak di bidang jasa dalam penyediaan air bersih. Sedangkan tujuan jangka panjangnya adalah untuk turut serta dalam melaksanakan pembangunan ekonomi nasional pada umumnya dalam rangka meningkatkan kesejahteraan dan memenuhi kebutuhan rakyat menuju masyarakat adil dan makmur berdasarkan Pancasila dan bertanggung jawab kepada pemerintah daerah sebagai pihak eksternal.

Dalam operasinya, PDAM baru dapat melakukan penagihan di bulan berikutnya setelah pelanggan menikmati layanan pemakaian air. Hal ini seringkali memunculkan tunggakan piutang terkait dengan pelanggan yang enggan membayar ataupun pelanggan yang tidak mampu/mengalami kesulitan keuangan. Permasalahan yang sering terjadi di PDAM yaitu di beberapa daerah pelanggan kesulitan untuk mendapatkan air sehingga mengalami air yang diterima oleh pelanggan seringkali kecil dan kadang tidak hidup, sehingga mengakibatkan pelanggan enggan membayar karena merasa tidak puas. Jika dikaji kesulitan dalam memperoleh air sangatlah tidak mudah dikarenakan musim panas (kemarau) pihak internal tidak dapat memuaskan pelanggan dalam memenuhi kebutuhan air sesuai dengan yang diharapkan. Hal ini dapat berpengaruh pada piutang. Oleh karena itu perlu adanya perhitungan rasio untuk mengetahui piutang tertagih dan tak tertagih pada PDAM di Kabupaten/Kota. Untuk mengetahui efektifitas pengelolaan piutang, salah satunya dengan melihat perputaran piutang pada perusahaan. Semakin tinggi tingkat perputaran piutang menandakan semakin efektif piutangnya. Apabila pengelolaan piutang kurang efektif maka profitabilitas perusahaan kurang baik. Karena piutang yang bertambah menyebabkan pendapatan perusahaan berkurang. Sehingga perusahaan perlu meningkatkan kebijakan kredit yang telah ditetapkan oleh perusahaan (Marlini dan Utami, 2019).

Pada saat perolehan, entitas mengukur piutang sebesar nilai kini dari kas yang akan diterima di masa depan (present value/ discounted of future cash flow). Piutang timbul dari beberapa jenis transaksi, yang paling umum ialah dari penjualan barang ataupun jasa. Semua piutang yang diharapkan akan ditagih menjadi kas dalam waktu satu tahun di dalam neraca disajikan sebagai aktiva lancar. Nilai piutang dapat diukur dengan mengurangkan jumlah piutang seluruhnya dengan penyisihan piutang tak tertagih. Cara ini bertujuan agar jumlah piutang yang dilaporkan pada neraca dapat menunjukkan jumlah yang wajar dalam mengukur jumlah penghasilan yang diterima dari piutang. Risiko tak tertagihnya piutang dari pihak luar perusahaan disebabkan karena adanya pelanggan yang tidak mampu melunasi kewajibannya pada saat jatuh tempo karena bangkrut, meninggal dunia atau karena sebab lainnya. Adapun risiko yang berasal dari dalam perusahaan dapat disebabkan karena kelalaian dan penyalahgunaan oleh karyawan perusahaan yang bersangkutan (Yusnaini et.al., 2021).

Pengakuan piutang dilakukan saat timbulnya piutang yaitu pada saat terjadinya penjualan kredit. Permasalahan yang dihadapi oleh PDAM antara lain sebagai berikut:

a) PDAM memiliki piutang yang tidak tertagih yang cukup besar, yang berasal dari periodeperiode sebelumnya yang telah terakumulasi, namun belum dapat dihapuskan karena mekanisme penghapusan yang harus melalui publikasi di surat kabar nasional.

b) PDAM belum mengestimasi penurunan nilai piutang.

c) PDAM belum memiliki sistem dan aplikasi yang andal dalam pengelolaan piutang. 
Berdasarkan latar belakang permasalahan yang terjadi di PDAM di Wilayah Sumatera Selatan dan Bangka Belitung maka solusi yang ditawarkan kepada PDAM adalah dengan melakukan sosialiasi, pelatihan, dan pendampingan manajemen atas impelementasi PSAK 71 dalam menghitung penurunan nilai piutang. Impelementasi PSAK 71 merupakan sebuah terobosan besar dalam peningkatan kualitas pelaporan keuangan terkait pengakuan penurunan nilai instrumen keuangan sehingga informasi yang dihasilkan lebih tepat waktu, relevan dan dapat dipahami oleh pengguna laporan keuangan. PSAK 71 memperkenalkan metode kerugian kredit ekspektasian (expected credit loss impairment model) yang lebih melihat ke depan dalam mengukur kerugian penurunan nilai instrumen keuangan.

Berbeda dengan PSAK 55 yang mengakui kerugian kredit pada saat peristiwa kerugian kredit terjadi, metode yang diperkenalkan PSAK 71 ini mensyaratkan setiap tanggal pelaporan entitas menilai apakah risiko kredit atas instrumen keuangan telah meningkat secara signifikan sejak pengakuan awal menggunakan informasi forward-looking yang wajar dan terdukung (reasonable and supportable information). Laporan keuangan akan mencerminkan manajemen risiko entitas lebih baik dibandingkan standar akuntansi sebelumnya yaitu PSAK 55.

\section{STUDI PUSTAKA}

\subsection{Pengertian Piutang}

Piutang salah satu aset yang cukup penting bagi pemerintah daerah, baik dari sudut pandang potensi kemanfaatannya maupun dari sudut pandang akuntabilitasnya. Semua standar akuntansi menempatkan piutang sebagai aset yang penting dan memiliki karakteristik tersendiri baik dalam pengakuan, pengukuran maupun pengungkapannya. Piutang adalah hak pemerintah untuk menerima pembayaran dari entitas lain termasuk wajib pajak/bayar atas kegiatan yang dilaksanakan oleh pemerintah (Buletin Teknis SAP Nomor 02 tahun 2005). Hal ini senada dengan berbagai teori yang mengungkapkan bahwa piutang adalah manfaat masa depan yang diakui pada saat ini.

Penyisihan piutang tak tertagih adalah taksiran nilai piutang yang kemungkinan tidak dapat diterima pembayarannya dimasa akan datang dari seseorang dan/atau korporasi dan/atau entitas lain. Nilai penyisihan piutang tak tertagih tidak bersifat akumulatif tetapi diterapkan setiap akhir periode anggaran sesuai perkembangan kualitas piutang. Penilaian kualitas piutang untuk penyisihan piutang tak tertagih dihitung berdasarkan kualitas umur piutang, jenis/karakteristik piutang, dan diterapkan dengan melakukan modifikasi tertentu tergantung kondisi dari debitornya. Mekanisme perhitungan dan penyisihan saldo piutang yang mungkin tidak dapat ditagih, merupakan upaya untuk menilai kualitas piutang.

\subsection{Pengakuan Piutang}

Piutang diakui saat timbul klaim/hak untuk menagih uang atau manfaat ekonomi lainnya kepada entitas lain. Piutang dapat diakui ketika:

1. diterbitkan surat ketetapan/dokumen yang sah; atau

2. telah diterbitkan surat penagihan dan telah dilaksanakan penagihan;

3. belum dilunasi sampai dengan akhir periode pelaporan.

Peristiwa-peristiwa yang menimbulkan hak tagih, yaitu peristiwa yang timbul dari pemberian pinjaman, penjualan, kemitraan, dan pemberian fasilitas/jasa, diakui sebagai piutang dan dicatat sebagai aset di neraca, apabila memenuhi kriteria:

1. harus didukung dengan naskah perjanjian yang menyatakan hak dan kewajiban secara jelas;

2. jumlah piutang dapat diukur;

3. telah diterbitkan surat penagihan dan telah dilaksanakan penagihan; dan

4. belum dilunasi sampai dengan akhir periode pelaporan. 


\subsection{Pengukuran Piutang}

Pengukuran piutang pendapatan adalah sebagai berikut:

1. disajikan sebesar nilai yang belum dilunasi sampai dengan tanggal pelaporan dari setiap tagihan yang ditetapkan berdasarkan surat ketetapan kurang bayar yang diterbitkan; atau

2. disajikan sebesar nilai yang belum dilunasi sampai dengan tanggal pelaporan dari setiap tagihan yang telah ditetapkan terutang oleh Pengadilan Pajak untuk Wajib Pajak (WP) yang mengajukan banding;

3. disajikan sebesar nilai yang belum dilunasi sampai tanggal pelaporan dari setiap tagihan yang masih proses banding atas keberatan dan belum ditetapkan oleh majelis tuntutan ganti rugi.

Piutang pendapatan diakui setelah diterbitkan surat tagihan dan dicatat sebesar nilai nominal yang tercantum dalam tagihan. Secara umum unsur utama piutang karena ketentuan perundangundangan ini adalah potensi pendapatan. Artinya piutang ini terjadi karena pendapatan yang belum disetor ke kas daerah oleh wajib setor. Oleh karena setiap tagihan oleh pemerintah wajib ada keputusan, maka jumlah piutang yang menjadi hak pemerintah daerah sebesar nilai yang tercantum dalam keputusan atas penagihan yang bersangkutan.

\subsection{Penilaian Piutang}

Piutang disajikan sebesar nilai bersih yang dapat direalisasikan (net realizable value). Nilai bersih yang dapat direalisasikan adalah selisih antara nilai nominal piutang dengan penyisihan piutang. Penggolongan kualitas piutang merupakan salah satu dasar untuk menentukan besaran tarif penyisihan piutang. Penilaian kualitas piutang dilakukan dengan mempertimbangkan jatuh tempo/umur piutang dan perkembangan upaya penagihan yang dilakukan oleh pemerintah daerah. Kualitas piutang didasarkan pada kondisi piutang pada tanggal pelaporan. Dasar yang digunakan untuk menghitung penyisihan piutang adalah kualitas piutang.

\subsection{Penerapan PSAK 71 atas Piutang}

SAK atau yang juga dikenal sebagai pernyataan standar akuntansi keuangan merupakan sekumpulan aturan yang mengatur mengenai tata cara penghitungan, pengklasifikasian, serta pencatatan akuntansi di Indonesia. Pada tahun 2017, Dewan Standar Akuntansi Keuangan (DSAK) telah merilis tiga Pernyataan Standar Akuntansi Keuangan (PSAK) baru yaitu PSAK 71, 72, dan 73 yang mulai diimplementasikan / efektif mulai pada tahun 2020 ini. Dikeluarkannya PSAK yang baru ini merupakan bagian dari usaha otoritas untuk mengadopsi sistem dari International Financial Reporting Standards (IFRS) yang dikeluarkan oleh International Accounting Standard Board (IASB). Poin-poin yang diatur oleh ketiga PSAK yang baru ini yakni meliputi, PSAK 71 mengatur mengenai instrumen keuangan, PSAK 72 mengatur mengenai pendapatan dari kontrak dengan pelanggan, dan PSAK 73 mengatur tentang sewa.

Pernyataan Standar Akuntansi Keuangan (PSAK) 71 memberi panduan tentang pengakuan dan pengukuran instrumen keuangan. Standar yang mengacu kepada International Financial Reporting Standard (IFRS) 9 ini akan menggantikan PSAK 55 yang sebelumnya berlaku. Selain soal klasifikasi aset keuangan, salah satu poin penting PSAK 71 adalah soal pencadangan atas penurunan nilai aset keuangan yang berupa piutang, pinjaman, atau kredit. Standar baru ini mengubah secara mendasar metode penghitungan dan penyediaan cadangan untuk kerugian akibat pinjaman yang tak tertagih. Jika berdasarkan PSAK 55, kewajiban pencadangan baru muncul setelah terjadi peristiwa yang mengakibatkan risiko gagal bayar (incurred loss), PSAK 71 memandatkan korporasi menyediakan pencadangan sejak awal periode kredit. Kini, dasar pencadangan adalah ekspektasi kerugian kredit (expected credit loss) yang didasarkan berbagai faktor, termasuk di dalamnya proyeksi ekonomi di masa mendatang.

Berdasarkan standar akuntansi baru ini, korporasi harus menyediakan cadangan kerugian atas penurunan nilai kredit (CKPN) untuk semua kategori kredit atau pinjaman, baik itu yang berstatus 
lancar (performing), ragu-ragu (underperforming), maupun macet (non-performing). Misalnya pada kredit lancar, korporasi harus menyediakan CKPN berdasarkan ekspektasi kerugian kredit dalam 12 bulan mendatang (Brama, 2019). Oleh sebab itu, PSAK 71 mengharuskan perbankan memiliki cadangan kerugian penurunan nilai (CKPN) yang lebih besar dibanding dengan ketentuan regulasi sebelumnya. Hal ini dikarenakan PSAK 71 mewajibkan perusahaan untuk menyediakan pencadangan sejak awal periode kredit.

\section{METODE PELAKSANAAN}

Pelaksanaan pengabdian masyarakat di lakukan secara online melalui ZOOM Virtual Meeting pada tanggal 21 Oktober 2020, dengan peserta staff pengelola piutang usaha PDAM di wilayah Sumatera Selatan dan Bangka Belitung. Metode pelaksanaan pengabdian yang akan dilakukan dengan menggunakan metode ceramah, tutorial dan diskusi. Adapun sistematika pelaksanaan kegiatan pengabdian ini dengan menggunakan metode ceramah dimana peserta diberikan materi mengenai PSAK 71 (Instrumen Keuangan). Dilanjutkan dengan metode tutorial dengam memberikan contoh ilustratif bagaimana melakukan menghitung Cadangan Kerugian Penurunan Nilai dengan menggunakan Expected Credit Loss (ECL). Kemudian diakhiri dengan diskusi dan tanya jawab dengan peserta.

\section{HASIL DAN PEMBAHASAN}

Kegiatan pengabdian ini dilaksanakan selama satu hari yaitu pada tanggal 21 Oktober 2020 menggunakan aplikasi virtual meeting Zoom. Dari total undangan yang disampaikan kepada 23 PDAM di Wilayah Sumatera Selatan dan Bangka Belitung, sebanyak 21 PDAM yang mengikuti pelatihan. Kegiatan ini diikuti oleh 45 orang peserta yang merupakan staff PDAM bagian pengelolaan Piutang Usaha dari PDAM Wilayah di Sumatera Selatan dan Bangka Belitung. Daftar hadir peserta terdapat di Lampiran. Kegiatan pengabdian dimulai dengan pembukaan oleh MC dilanjutkan kata sambutan dari Ketua Tim Pengabdian. Selanjutnya pemaparan materi dilakukan oleh Tim Pengabdian melalui ceramah, kemudian dilanjutkan dengan simulasi penyusunan daftar aset dan penyusutan Piutang Usaha menggunakan aplikasi Excel. Peserta juga diberikan modul cetak yang sudah dikirimkan sebelumnya. Setelah sesi materi dilanjutkan dengan sesi diskusi dan tanya jawab dimana para peserta juga dapat berkonsultasi dengan tim pengabdian atas daftar aset dan perhitungan penyusutan serta pengelolaan aset yang sudah dibuat para staff PDAM. Panitia juga bersedia untuk melakukan pendampingan setelah acara pelatihan. Pada saat sesi diskusi dan tanya jawab, peserta sangat antusias dalam mengajukan pertanyaan seputar permasalahan tentang pengelolaan Piutang Usaha yang dihadapi. Dari hasil diskusi tersebut dapat diidentifikasi permasalahan atas pengelolaan yang terjadi di PDAM.

Pengimplementasian PSAK 71 diinisiasi karena besarnya manfaat yang diperoleh yaitu memprediksi risiko ekonomi atas laporan keuangan, sehingga mampu melindungi investor dari kerugian yang timbul dari suatu siklus ekonomi (Sapta \& Hariri, 2019). Metode pencadangan kerugian piutang (expected loss) memperhitungkan dampak perubahan ekonomi terhadap risiko kredit yang menyebabkan probabilitas dari penurunan nilai di masa depan. Pehitungan ini berdasarkan pada nilai historis, nilai sekarang, dan nilai prediksi (expected) di masa depan, dimulai saat kontrak kredit dimulai tanpa menunggu adanya penurunan nilai (Arifullah \& Firmansyah, 2021). Kriteria penurunan nilai dibuktikan dari adanya kesulitan keuangan yang signifikan dari debitor, adanya wanprestasi (e.g., melewati waktu tempo pembayaran), adanya keringanan pinjaman sebagai akibat dari kesulitan keuangan yang dialami debitor (e.g., meregulasi ulang kontrak pinjaman), adanya pernyataan pailit dari debitor, kehilangan pasar aktif, atau adanya indikasi penurunan atas estimasi arus kas masa depan. 


\section{Mengenal PSAK 71}
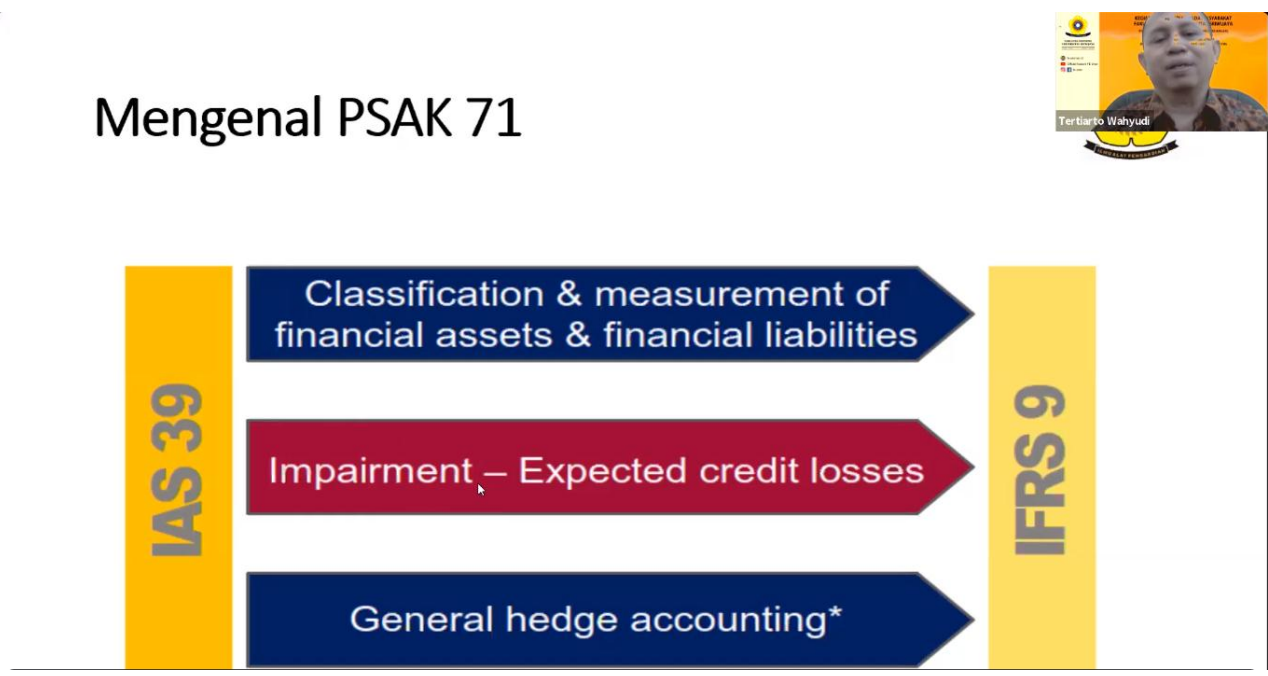

Gambar 1. Penyampaian materi oleh narasumber Pak Tertiarto)

Lebih lanjut, sistem pengendalian piutang yang baik meningkatkan efektivitas arus kas yang pada akhirnya memberikan kontribusi positif terhadap kinerja perusahaan. Sebaliknya, pengendalian piutang yang buruk cepat atau lambat akan berakibat fatal karena ketidakmampuan perusahaan untuk mengelola arus kas yang sehat (Rivandi \& Septiana, 2020). Komposisi piutang tertagih yang terlalu tinggi perlu menjadi perhatian bagi perusahaan, sebagai indikasi adanya arus kas yang tidak lancar. Faktor yang menyebabkan timbulnya piutang tak tertagih secara eksternal adalah kondisi ekonomi makro, misalnya krisis berkepanjangan, turunnya kurs mata uang, epidemi yang bertransformasi menjadi pandemi, sedangkan secara internal disebabkan oleh berbagai faktor yang pada mulanya bermuara dari sistem pengawasan perusahaan yang tidak efektif (Ismawati, Naidah, \& Razak, 2020).

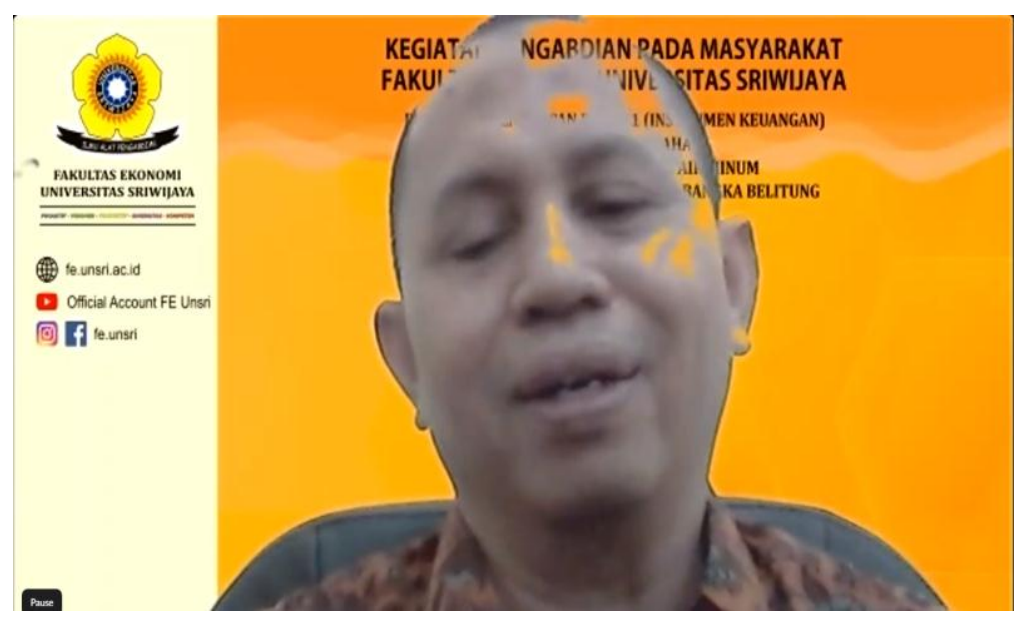

Gambar 2. Narasumber (Pak Tertiarto) sedang menjawab pertanyaan peserta

Dalam penerapan PSAK 71, PDAM juga menghadapi permasalahan rumit lainnya, yaitu pandemi COVID-19. Pandemi ini mengakibatkan perekonomian secara keseluruhan melambat. Berdasarkan Rilis BPS mengenai Data Pertumbuhan Ekonomi Triwulan II 2020 melalui kanal youtube BPS, pertumbuhan ekonomi Indonesia secara year on year (yoy) sebesar minus 5,32\%. Kontraksi ini menjadi pertumbuhan ekonomi terendah sejak krisis tahun 1998. Hal ini disebabkan menurunnya PDB Indonesia hampir pada seluruh sektor. Jika PDB dihitung berdasarkan lapangan usaha, pertumbuhan ekonomi Indonesia minus 4,19\% (qoq) dan minus 5,32\%. Sektor usaha yang paling terdampak pandemi adalah sektor transportasi dan 
perdagangan, dengan pertumbuhan minus $-29,22 \%$ (qoq) dan minus $30,84 \%$ (yoy). Pandemi membuat sektor usaha menjadi semakin sulit dalam mempertahankan bisnisnya, secara tidak langsung mengakibatkan sulitnya para debitur perbankan dalam membayar hutang-hutangnya. Oleh karena itu, OJK memberikan relaksasi kredit usaha mikro dan kecil untuk nilai dibawah Rp10 miliar, baik kredit maupun pembiayaan yang diberikan oleh bank atau industri keuangan non-bank kepada debitur. Debitur akan diberikan fasilitas penundaan sampai dengan 1 (satu) tahun serta penurunan bunga kredit. Pemerintah juga memberikan kelonggaran bagi perbankan untuk tidak meningkatkan CKPN perusahaan. Namun, hal ini hanya berlaku bagi debitur yang kinerjanya baik dan saat ini terkena dampak pandemi. Apabila debitur diperkirakan tidak dapat pulih dalam menghadapi pandemi, maka bank diwajibkan untuk membentuk CKPN. Hal ini dilakukan berdasarkan peraturan yang tercantum dalam POJK No. 11/POJK.03/2020 tentang Stimulus Perekonomian Nasional sebagai Kebijakan Countercyclical (Otoritas Jasa Keuangan, 2020).

Karena itu, pengenalan tentang Pengelolaan Piutang Usaha untuk memberikan motivasi tentang penyusunan dan pengelolaan Piutang Usaha yang sesuai dengan peraturan yang berlaku bagi PDAM penting untuk dilakukan, sehingga diharapkan kinerja dari PDAM semakin efisien dan investasi pada aset dapat semakin ditingkatkan. Permasalahan yang paling dominan disini adalah bagaimana dapat memberikan wawasan baru, mengembangkan pola pikir dan menumbuhkan tingkat kesadaran bagi peserta perwakilan dari 20 PDAM di Wilayah Sumatera Selatan dan Bangka Belitung untuk mulai membiasakan menyusun dan mengelola Piutang Usaha dengan baik dan efisien. Evaluasi kegiatan yang dilakukan selama proses kegiatan berlangsung, yaitu pada saat peserta berhasil menjawab pertanyaan-pertanyaan terkait materi yang sudah disampaikan serta bisa mensimulasikan pembuatan laporan dan perhitungan penurunan nilai Piutang Usaha.

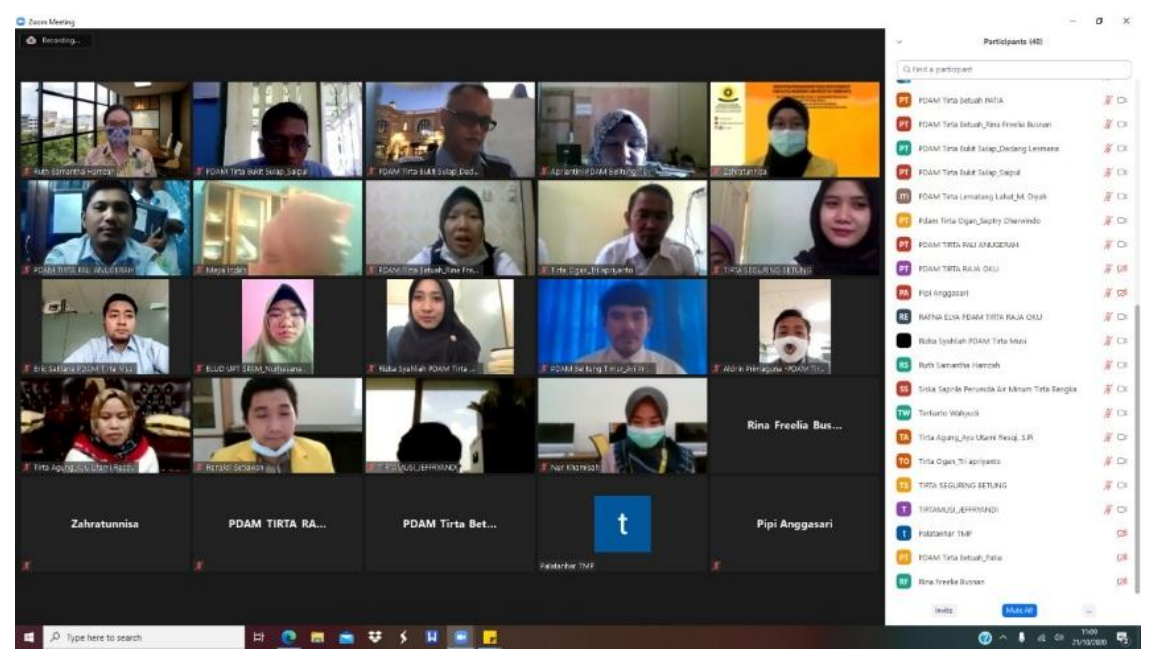

Gambar 3. Foto bersama peserta

\section{SIMPULAN}

Hasil pelaksanaan kegiatan pengabdian kepada masyarakat ini dapat disimpulkan bahwa pengelolaan piutang usaha PDAM yang baik akan memiliki dampak yang sangat besar bagi peningkatan pendapatan usaha PDAM dan lebih lanjut akan meningkatkan Pendapatan Asli Daerah. Dalam pelaksanaan pengabdian ini ada beberapa pertanyaan berkaitan dengan perhitungan penurunan nilai piutang usaha dengan metode Expected Credit Loss yang memang masih relatif baru bagi staff PDAM. Dengan demikian dalam pelaksanaan pengabdian ini mereka aktif berdiskusi berkaitan dengan menghitung penurunan nilai piutang usaha PDAM. Perlu adanya pendampingan bagi staff pengelola PDAM di wilayah Sumatera Selatan dan Bangka Belitung dalam menetapkan, menghitung, memperhitungkan berkaitan dengan piutang usahanya. 


\section{UCAPAN TERIMA KASIH (ACKNOWLEDGMENTS)}

Terima kasih kami ucapkan kepada Fakultas Ekonomi Universitas Sriwijaya atas dana Pengabdian Kepada Masyarakat Tahun 2020 yang telah direalisasikan, dan kepada seluruh peserta pelatihan dari PDAM Sumatera Selatan dan Bangka Belitung yang telah memberikan masukan atas kegiatan pengabdian.

\section{REFERENSI}

Ardhienus. (2020). Indikator Kesehatan Bank Saat Pandemi. Tersedia pada: https://analisis.kontan.co.id/news/indikator-kesehatan-bank-saat-pandemi.

Arifullah, N. \& Firmansyah, A. (2021). Pencadangan Piutang pada Perusahaan Sub-sektor Perbankan di Indonesia: Implementasi Penerapan PSAK 71. CURRENT: Jurnal Kajian Akuntansi dan Bisnis Terkini. 2(1), 122-142.

Brama, A., \& Wahyana, C. (2019). Standar Akuntansi Baru PSAK 71, 72, dan 73 Berlaku 2020, Ini Perbedaannya.

Buletin Teknis Standar Akuntansi Pemerintahan Nomor 02 tahun 2005.

Carter, K, W. (2009). Akuntansi Biaya. Buku 1. Edisi Keempat Belas, Jakarta: Salemba Empat.

Ikatan Akuntan Indonesia. (2011). Standar Akuntansi Keuangan. Dewan Standar Akuntansi Keuangan, Jakarta.

Institut Akuntan Publik Indonesia. (2011). Ilustrasi Laporan Keuangan dengan Penerapan Standar Akuntansi Keuangan Entitas Tanpa Akuntabilitas Publik. Jakarta IAPI.

Ismawati, Naidah, \& Razak, L. A. (2020). Audit Kepatuhan Pengelolaan Piutang dalam Meminimalisir Piutang Tak Tertagih (Studi Kasus PT Bank Negara Indonesia (Persero) Tbk Cabang Makassar). Profitability: Jurnal Ilmu Manajemen, 4(2), 51-64.

Kesuma, N., Nurullah, A., \& Meirawati, E. (2020). Pendampingan Pencatatan dan Pembukuan Sederhana bagi Orang Pribadi sebagai Pelaku Usaha di Kelurahan Talang Jambe, Kota Palembang. Sricommerce: Journal of Sriwijaya Community Services, 1(2), 101-106. doi:https://doi.org/10.29259/jscs.v1i2.18.

Marlini, W., \& Widya Utami, M. (2019). Analisis Perputaran Piutang, Piutang Rata-Rata dan Rasio Piutang Atas Pendapatan Terhadap Profitabilitas pada PDAM Tirta Bumi Sentosa Kabupaten Kebumen. Jurnal E-Bis (Ekonomi-Bisnis), 3(1), 84 - 95. https://doi.org/10.37339/e-bis.v3i2.122

Mulyadi. (2007). Akuntansi Biaya. Yogyakarta. YKPN.

Mulyadi. (2010). Akuntansi Manajemen: Konsep, Manfaat dan Rekayasa. Edisi 3. Salemba Empat, Jakarta.

Otoritas Jasa Keuangan. (2020). Frequently Asked Questions Restrukturisasi Kredit/Pembiayaan terkait Dampak COVID-19.

Rivandi, M. \& Septiana, G. (2020). Pengaruh Pengelolaan Piutang terhadap Efektivitas Arus Kas pada PT Satria Lestari Multi. Jurnal Manajemen Universitas Bung Hatta, 15(2), 23-30. DOI: https://doi.org/10.37301/jmubh.v15i2.16896.

Sapta, A., \& Hariri, H. (2019). Implementasi Pernyataan Standar Akuntansi Keuangan (Psak) Atas Transaksi Murabahah (Studi Kasus Pada Bank Syariah Di Indonesia). Jurnal VOK@SINDO, 7(2), 148-173.

Undang-Undang Nomor 12 Tahun 2008 Perubahan atas Undang-U.ndang Nomor 32 tahun 2004 tentang Pemerintahan Daerah.

Undang-Undang Nomor 23 Tahun 2014 Tentang Pemerintah Daerah.

Yuliani, Y., \& Rahdriawan, M. (2015). Kinerja Pelayanan Air Bersih Berbasis Masyarakat di Kelurahan Tugurejo Kota Semarang. Jurnal Pengembangan Kota, 3(1), 11-25. doi:10.14710/jpk.3.1.11-25.

Yusnaini, Y., Burhanudin, B., \& Khamisah, N. (2021). Training on the Preparation of Simple Financial Statements for Mosque /Mushollah and Youth Organizations of Mosque in the Kerinjing Village. Sricommerce: Journal of Sriwijaya Community Services, 2(1), 77-84. 